\title{
Application of Bromelain Extract for Muscle Foods Tenderization
}

\author{
Sunantha Ketnawa, Saroat Rawdkuen* \\ Food Technology Program, School of Agro-Industry, Mae Fah Luang University, Chiang Rai, Thailand. \\ Email: *saroat@mfu.ac.th
}

Received February 11 ${ }^{\text {th }}, 2011$; revised April 12 ${ }^{\text {th }}, 2011$; accepted April $19^{\text {th }}, 2011$.

\begin{abstract}
This study investigates the tenderizing effects of bromelain extract (BE) obtained from the top phase of an aqueous two-phase system comprising of 18\% PEG-6000 and 17\% $\mathrm{MgSO}_{4}$ in muscle foods. Uniform-sized chunks of beef, chicken and squid were marinated with different concentrations of BE (0,3\%,7\%, 10\% and 20\% (w/w)) for $1 \mathrm{~h}$ at room temperature. The physico-chemical and quality characteristics of the marinated samples were determined. Decreases in pH and moisture content were observed in the BE-treated samples, but the TCA-soluble peptides content significantly increased $(p<0.05)$. Water holding capacity and cooking yields decreased in all of the tested samples, especially when the concentration of BE increased. In addition, a reduction of meat firmness and toughness were also observed in all of the samples when compared to the control $(p<0.05)$. Electrophoretic patterns also revealed extensive proteolysis and a reduction in number and intensity of the protein bands in all of the treated samples. At the microstructural level, tissue fibers were broken, cell membranes were more strongly degraded, the connections between the sarcolemma and the myofibrils were disappeared, and the generation of numerous gaps could be clearly observed when 20\% (w/w) BE was added. The results showed that the bromelain extract derived from the two-phase extraction of a pineapple peel could be used as an effective meat tenderizer.
\end{abstract}

Keywords: Bromelain, Pineapple Peel, Aqueous Two Phase System, Muscle Food, Meat Tenderization

\section{Introduction}

Toughness is one of the most common quality characteristics of meat. Toughness is due to a range of factors including the amount of intramuscular connective tissue, intramuscular fat and the length of the sarcomere [1]. Meat toughness can be subdivided into actomyosin toughness and background toughness. Actomyosin toughness is attributable to changes in myofibrillar proteins, whereas background toughness is attributable to connective tissues [2]. A number of attempts have been made to tenderize and improve the qualities of such meat. These studies were mainly able to reduce the amounts of detectable connective tissues either chemically and including the use of enzymes [3-7], phosphates, salts [8] and calcium chloride [9]. There have also been attempts to physically tenderize meat by pressure treatments [10], electrical stimulation [11] and blade tenderization [8]. Treatment by proteolytic enzymes is a popular method for meat tenderization. Proteolytic enzymes derived from plants such as papain, bromelain and ficin have been widely used as meat tenderizers in most parts of the world [6]. Proteolytic plant enzymes are superior to bacterial derived enzymes mainly because of safety problems such as pathogenicity or other disadvantageous effects [2].

Bromelain is reported to also be present in pineapple wastes such as in cores, peels and leaves. The bromelain in their waste materials are in relatively smaller quantities as compared to in the stems and fruits [12]. Bromelain is a plant protease of the sub-group of thiol (cysteine) proteinases such as ficin from figs [13], papain from papaya [14] and protease from ginger [15]. Naveena et al. [6] revealed that protease from Cucumis trigonus Roxb and Zingiber officinale Roscoe improved the tenderness and the overall qualities of tough buffalo meat. According to the previous work, the bromelain extract from pineapple peels ( $P h u$ Lae cultv.) by using an aqueous two-phase system (18\% PEG-6000 and 17\% $\mathrm{MgSO}_{4}$ ) exhibited the highest protease activity recovery. Therefore, applying extracted bromelain into the muscle foods system was the motivation for this study.

Hence, the current investigation applies bromelain 
extract obtained from the top phase of a selected aqueous two phase system to the muscle sample. This study also investigates the effects of the bromelain extract on the physico-chemical and quality properties of the samples.

\section{Materials and Methods}

\subsection{Chemicals and Raw Materials}

Sodium dodecyl sulfate (SDS), cysteine, ethylene diamine tetraacetic acid (EDTA), casein and bovine serum albumin (BSA) were obtained from Fluka (Buchs, Switzerland). Beta-mercaptoethanol ( $\beta \mathrm{ME}$ ), Coomassie Brilliant Blue G-250, polyethylene glycol (PEG) and electrophoresis reagents were purchased from Sigma Chemical Co. (St. Louis, MO, USA). Magnesium sulfate $\left(\mathrm{MgSO}_{4}\right)$ and trichloroacetic acid (TCA) were obtained from Merck (Darmstadt, Germany).

The pineapple peel (Phu Lae cultv.) was obtained from a shop in Nang Lae subdistrict, Muang, Chiang Rai, Thailand. Beef, chicken and squid muscles were purchased from 'Makro' supermarket, Chiang Rai, Thailand.

\subsection{Bromelain Extract Preparation}

The crude extract was derived by blending the pineapple peels with a cold extraction buffer ( $0.1 \mathrm{M}$ sodium phosphate buffer with $15 \mathrm{mM}$ cysteine and $2 \mathrm{mM}$ EDTA, $\mathrm{pH}$ 7.0). The peel extracts were subjected to partitioning with an $18 \%$ PEG-6000 and $17 \% \mathrm{MgSO}_{4}$ system, following the method used in Ketnawa et al. [16]. A powder from the bromelain extract (BE) was obtained by freeze drying the top phase of the aqueous two-phase system fraction.

\subsection{Marination of Meat Samples by Bromelain Extract}

The uniform-sized chunks of beef and chicken $(3 \times 3 \times 3$ $\mathrm{cm})$ and squid $(3 \times 3 \times 0.5 \mathrm{~cm})$ were weighed and then sprinkled by a powder of BE $(0,3 \%, 7 \%, 10 \%$ and $20 \%$ $(w / w))$. Ten pieces of meat were used for each treatment. After mixing thoroughly, the chunks of meat were placed in a plastic box and then left at room temperature for 60 min before determining the physico-chemical and quality characteristics as described below.

\subsection{Physical Properties Determinations}

\subsubsection{Textural Properties}

The texture was analyzed by using a TA.XT2 texture analyzer (Stable Micro Systems, Surrey, UK), equipped with a Warner-Bratzler blade (square shape) in accordance with the method used in Espe et al. [17]. Seven rectangular shaped samples of raw beef, raw chicken and raw squid were prepared. Each sample was cut perpendicular to the longitudinal orientation of the muscle fibers. The blade was pressed down at a constant speed of $2 \mathrm{~mm} \cdot \mathrm{s}^{-1}$ through the sample. Maximum shear force (N) and total work ( N.Sec) were recorded.

\subsubsection{Water-Holding Capacity (WHC)}

WHC was determined according to method used in Wardlaw et al. [18]. Minced meat (20 g) was placed in a centrifuge tube containing $30 \mathrm{ml}$ of $0.6 \mathrm{M} \mathrm{NaCl}$ and was stirred with a glass rod for $1 \mathrm{~min}$. The tube was then kept at $4 \pm 1^{\circ} \mathrm{C}$ for $15 \mathrm{~min}$, stirred again, and then centrifuged at $3000 \mathrm{~g}$ (PLC-05, Industrial Corp., Taipei, Taiwan) for 25 min. The supernatant was measured, and the WHC was expressed in percentage as the following equation:

$$
\text { WHC }(\%)=\frac{\text { Volume of } \mathrm{NaCl} \text { before centrifuge }- \text { Volume of } \mathrm{NaCl} \text { after centrifuge }}{\text { Volume of } \mathrm{NaCl} \text { before centrifuge }} \times 100
$$

\subsubsection{Cooking Yield}

The treated samples (10 g) were steamed for $1 \mathrm{~min}$ and then cooled at room temperature. The cooked sample was surface-dried with a filter paper and reweighed using an analytical balance (Sartorius, ED224S Sartorius AG, Goettingen, Germany). The cooking yield was calculated by the difference in raw and cooked weights as following:

$$
\text { Cooking Yield(\%) }=\frac{\text { Weight of cooked chunks }}{\text { Weight of raw chunks }} \times 100
$$

\subsubsection{Scanning Electron Microscopy (SEM)}

Microstructures of the samples were determined by using a scanning electron microscope (LE01450VP, Cam- bridge, UK). Muscle specimens for SEM were prepared from inside of meat with a thickness of $2-3 \mathrm{~mm}$ were fixed with $2.5 \%(\mathrm{v} / \mathrm{v})$ glutaraldehyde in an $0.2 \mathrm{M}$ phosphate buffer $(\mathrm{pH} 7.2)$ for $2 \mathrm{~h}$. The samples were then rinsed for $1 \mathrm{~h}$ with distilled water before being dehydrated in ethanol with a serial concentration of $50 \%, 70 \%$, $80 \%, 90 \%$ and $100 \%(\mathrm{v} / \mathrm{v})$. They were then critical-point-dried (Balzers mod CPD 030, Blazers Process Systems, Vaduz, Liechtenstein) by using $\mathrm{CO}_{2}$ as a transition fluid. The dried samples were mounted on a bronze stub and sputter-coated with gold (Sputter coater, SC7620, Polaron, UK). The specimens were observed with a SEM with a magnification of $250 \times$ and $2000 \times$ at an acceleration voltage of $10 \mathrm{kV}$. 


\subsection{Chemical Properties Determination}

\subsection{1. $\mathrm{pH}$}

To determine $\mathrm{pH}, 10 \mathrm{~g}$ of the sample were homogenized with $50 \mathrm{ml}$ of chilled distilled water. The $\mathrm{pH}$ values were measured with a digital pH meter (Model pH 510, Eutech Instrument, Ayer Rajah Crescent, Singapore).

\subsubsection{Moisture Content}

The moisture content of the samples was determined according to the Association of Official Analytical Chemists (AOAC) method No. 950.46 [19].

\subsubsection{TCA-Soluble Peptides Content}

The TCA-soluble peptides content of the samples was measured by the method used in Benjakul et al. [20]. Two grams of the samples were weighed and then homogenized with $18 \mathrm{ml}$ of 5\% (w/v) TCA for $1 \mathrm{~min}$ and kept at $4^{\circ} \mathrm{C}$ for $1 \mathrm{~h}$ before they were centrifuged at 8000 $\times \mathrm{g}$ for $5 \mathrm{~min}$. Soluble peptides in the supernatant were measured by using the Lowry method [21]. The TCA soluble peptides content was calculated as the $\mu$ mol of tyrosine/g of the samples.

\subsubsection{Electrophoresis}

SDS-PAGE was carried out according to the method in Laemmli et al. [22]. Samples (2 g) subjected to different treatment conditions were mixed with $18 \mathrm{ml}$ of $5 \%(\mathrm{w} / \mathrm{v})$ SDS solution $\left(85^{\circ} \mathrm{C}\right)$. The mixture was then homogenized using a homogenizer (IKA Ultra Turrax, T25D, KG, Germany). The homogenate was incubated at $85^{\circ} \mathrm{C}$ in a water bath for $1 \mathrm{~h}$ to dissolve the protein. It was then centrifuged at $8000 \times g$ for $5 \mathrm{~min}$ at room temperature using a centrifuge (PLC-05, Industrial Corp., Taipei, Taiwan) to remove the undissolved debris. The supernatants were mixed at a $1: 1(\mathrm{v} / \mathrm{v})$ ratio with the sample buffer (0.5 M Tris-HCl, pH 6.8 containing 4\% SDS, $20 \%$ glycerol and $10 \% \beta \mathrm{ME}$ ) and then boiled for $3 \mathrm{~min}$. The samples (20 $\mu$ g protein) were loaded into a polyacrylamide gel (10\% running and $4 \%$ stacking gels). Then, they were subjected to an electrophoresis set at a constant current of $15 \mathrm{~mA}$ per gel using a Mini Protean Tetra Cell unit (Bio-Rad Laboratories, Richmond, CA, USA). After electrophoresis, the gels were stained overnight with staining solution $(0.02 \%(\mathrm{w} / \mathrm{v})$ Coomassie Brilliant Blue R-250) in 50\% (v/v) methanol, and 7.5\% $(\mathrm{v} / \mathrm{v})$ acetic acid. The protein patterns were then visualized after destaining the gel until a clear background was achieved.

\subsection{Statistical Analysis}

The obtained data was statistically analyzed with the SPSS program for Windows (SPSS version 11.5, SPSS Inc., Chicago, IL, USA). Duncan's multiple-range test was used to compare the difference between means. The accepted level of significance for all comparisons was $p$ $<0.05$. Experiments were conducted in triplicate.

\section{Results and Discussion}

\subsection{Effects of Bromelain Extract on the Physical Properties of Muscle Foods}

\subsubsection{Textural Properties}

The shear force values significantly decreased in all of the BE-treated samples when compared to the control without the $\mathrm{BE}$ addition $(p<0.05)$. It was observed that the shear force values continuously decreased in all of the treated samples when the level of BE increased (Figure 1(a)). The firmness for the starting beef, chicken, and squid muscles were $570 \mathrm{~N}, 111 \mathrm{~N}$ and $314 \mathrm{~N}$ respectively. Adding 3\% (w/w) BE to the samples reduced the firmness of the samples by about $20 \%$, 28\% and $31 \%$ when compared to the control for beef, chicken and squid, respectively. When $20 \%(\mathrm{w} / \mathrm{w})$ of $\mathrm{BE}$ was added to the sample, firmness reduction of more than $61 \%$ was found when compared to the control. Reduction of meat firmness is results by the action of the proteolytic enzymes on

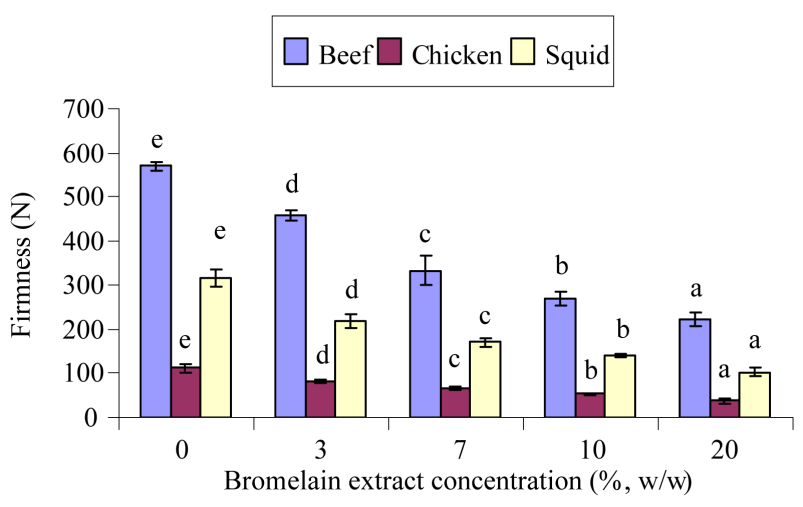

(a)

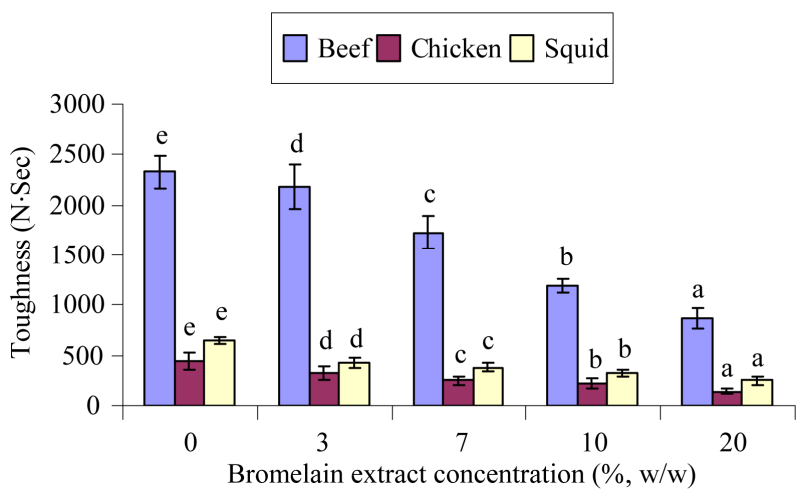

(b)

Figure 1. Firmness (a) and toughness (b) of muscle samples treated with different bromelain extract concentrations. Different letters each bar in the samples indicated significant differences $(p<0.05)$. 
myofibrillar proteins. When the breakdown of myofibrillar protein occurred, small peptides, or proteins with low molecular weight (MW), were generated and resulted in reducing the firmness of the meat samples.

The toughness of the treated meat samples are presented in Figure 1(b). The toughness is indicated by the amount of intramuscular connective tissue, intramuscular fat, and the length of the sarcomere [1]. This value is related to the acceptable meat quality for the consumer. The eating quality of muscle foods is directly related to meat toughness. Older animals normally produce the tough meat than that of young ones. The tougher the meat, the more connective tissues are present. Larger sized animals also normally give a larger amount of connective tissues rendering the meat to be toughes. Tenderization associated with postmortem aging is due to endogenous enzyme activity to the muscle. Proteolytic enzymes such as plant proteases affect the meat tenderization [1]. According to Naveena et al. [6,23], Warner-Bratzler shear force values were diminished by plant proteases, including cucumis and ginger powders. Naveena et al. [6] also observed that in buffalo meat with extensive muscle fiber and connective tissue degradation, shear force values decreased when ginger rhizome extract was added. Reductions in shear force values with ginger extract treatment was also reported in chevon muscles [7], buffalo [24] and spent hen meat [25].

\subsubsection{Water Holding Capacity and Cooking Yield}

There was a significant reduction of WHC in all of the treated samples, especially when the concentration of $\mathrm{BE}$ increased $(p<0.05)$. The lowest WHC values were observed in the treated beef muscle when compared with others (Table 1). The squid showed the highest WHC, while the highest value for each meat type was found in the untreated samples. The higher WHC in the control sample may be due to the overall reduction in the protein reactive group that is available for water binding [26].
The reduction in WHC in all of the treated samples might be due to lower $\mathrm{pH}$. This drop in $\mathrm{pH}$ may be responsible for the overall reduction in protein reactive groups available for water holding. Slight denaturation of sarcoplasmic proteins, which play an important role in determining WHC, could be the reason for lowering WHC [27]. The WHC of meat is very important since many physical properties such as color, texture and firmness are partially dependent on the WHC. However, in this experiment, the lowered WHC in the BE treated samples are probably due to the denaturation of myofibrillar proteins, which play a role in water retention. BE could hydrolyze these proteins into small peptides or amino acids, which then could not function properly. Reduced WHC results from myofibrillar shrinkage, as well as by the movement of water from the myofilament space in to the extra-cellular space. There are three main factors involved in the shrinkage and/or swelling of the myofibrils: the onset of rigor mortis, the decline in $\mathrm{pH}$ and protein fragmentation [28].

In addition, all three BE-treated samples were significantly different from the control samples in the cooking yield $(p<0.05)$. Marinated meat samples with BE showed a reduction in cooking yield (Table 1). The cooking yield, inversely proportional to cooking loss, were found to decrease with the increase of $\mathrm{BE}$ in all samples. The highest and lowest cooking yield of starting meat was found in squid and beef muscles, respectively. When treated with $20 \%(\mathrm{w} / \mathrm{w}) \mathrm{BE}$, the highest and lowest value was also found in squid and beef, respectively. This result indicated that thermal treatment could remove more water from treated beef samples than that of squid muscles. It can be implied that the enzymes in BE could hydrolyze protein in beef more than in chicken and squid. Moreover, the addition of BE at different levels could possibly be due to the tenderizing effects of proteolytic enzymes from the pineapple peel. Pawar et al. [7]

Table 1. Physico-chemical properties of meat samples treated with bromelain extract at difference concentrations.

\begin{tabular}{|c|c|c|c|c|c|c|}
\hline \multirow{2}{*}{ Sample } & \multirow{2}{*}{ Properties } & \multicolumn{5}{|c|}{ Concentration $(\%, \mathrm{w} / \mathrm{w})^{* *}$} \\
\hline & & 0 & 3 & 7 & 10 & 20 \\
\hline \multirow[t]{4}{*}{ Beef } & $\mathrm{pH}^{*}$ & $5.28 \pm 0.01^{\mathrm{c}}$ & $5.27 \pm 0.01^{\mathrm{ab}}$ & $5.26 \pm 0.02^{\mathrm{ab}}$ & $5.26 \pm 0.02^{\mathrm{ab}}$ & $5.24 \pm 0.01^{\mathrm{a}}$ \\
\hline & Moisture (\%) ${ }^{*}$ & $74.64 \pm 0.29^{c}$ & $70.03 \pm 0.52^{b}$ & $69.71 \pm 0.53^{b}$ & $69.27 \pm 1.21^{\mathrm{b}}$ & $66.56 \pm 1.10^{\mathrm{a}}$ \\
\hline & WHC (\%) & $40.01 \pm 1.48^{\mathrm{e}}$ & $27.97 \pm 0.80^{d}$ & $22.36 \pm 0.68^{\mathrm{c}}$ & $16.25 \pm 00.49^{b}$ & $12.01 \pm 0.12^{\mathrm{a}}$ \\
\hline & Cooking yield (\%) & $77.89 \pm 2.31^{\mathrm{c}}$ & $63.67 \pm 1.80^{\mathrm{b}}$ & $62.38 \pm 1.67^{b}$ & $62.93 \pm 1.83^{\mathrm{b}}$ & $57.83 \pm 2.60^{\mathrm{a}}$ \\
\hline \multirow[t]{4}{*}{ Chicken } & $\mathrm{pH}$ & $5.93 \pm 0.03^{\mathrm{d}}$ & $5.81 \pm 0.01^{\mathrm{bc}}$ & $5.81 \pm 00.1^{\mathrm{bc}}$ & $5.78 \pm 0.02^{\mathrm{ab}}$ & $5.76 \pm 0.01^{\mathrm{a}}$ \\
\hline & Moisture (\%) & $75.78 \pm 1.27^{\mathrm{d}}$ & $71.17 \pm 0.39^{\mathrm{c}}$ & $66.58 \pm 0.81^{\mathrm{b}}$ & $66.26 \pm 0.59^{b}$ & $59.63 \pm 1.87^{\mathrm{a}}$ \\
\hline & WHC (\%) & $89.62 \pm 0.97^{\mathrm{e}}$ & $84.70 \pm 0.27^{\mathrm{d}}$ & $61.10 \pm 1.42^{\mathrm{c}}$ & $43.69 \pm 0.18^{\mathrm{b}}$ & $34.04 \pm 0.25^{a}$ \\
\hline & Cooking yield (\%) & $84.12 \pm 1.68^{\mathrm{c}}$ & $83.13 \pm 3.19^{c}$ & $76.05 \pm 1.24^{\mathrm{b}}$ & $75.09 \pm 2.96^{\mathrm{b}}$ & $72.74 \pm 3.51^{\mathrm{a}}$ \\
\hline \multirow[t]{4}{*}{ Squid } & $\mathrm{pH}$ & $7.04 \pm 0.01^{\mathrm{e}}$ & $6.79 \pm 0.01^{\mathrm{d}}$ & $6.70 \pm 0.06^{\mathrm{c}}$ & $6.44 \pm 0.01^{b}$ & $6.06 \pm 0.01^{\mathrm{a}}$ \\
\hline & Moisture (\%) & $84.07 \pm 0.10^{\mathrm{e}}$ & $80.74 \pm 0.22^{\mathrm{d}}$ & $78.91 \pm 0.44^{\mathrm{c}}$ & $77.11 \pm 0.31^{\mathrm{b}}$ & $75.53 \pm 0.6^{\mathrm{a}}$ \\
\hline & WHC (\%) & $100 \pm 0.00^{\mathrm{c}}$ & $99.36 \pm 0.03^{c}$ & $98.84 \pm 0.16^{\mathrm{c}}$ & $95.66 \pm 0.09^{b}$ & $87.80 \pm 1.40^{\mathrm{a}}$ \\
\hline & Cooking yield (\%) & $77.09 \pm 0.95^{\mathrm{d}}$ & $75.04 \pm 2.17^{\mathrm{c}}$ & $74.31 \pm 0.49^{\mathrm{bc}}$ & $73.07 \pm 1.79^{\mathrm{ab}}$ & $72.01 \pm 1.28^{\mathrm{a}}$ \\
\hline
\end{tabular}

\footnotetext{
${ }_{* * * *}^{*}$ Means \pm S.D. from triplicate determinations. ${ }^{* *}$ Different superscripts in the same row indicate the significant differences $(p<0.05)$. Number of observations $=$

**** 10 . Bromelain extract (BE) was obtained from the top phase of aqueous two phase system comprising of $18 \%$ PEG-6000 and $17 \% \mathrm{MgSO}_{4}$. The muscle samples were treated with difference concentrations of $\mathrm{BE}$ and then subjected to incubate at room temperature for $60 \mathrm{~min}$. before properties measurement.
} 
reported that the reduction of cooking yield in the treated sample when compared to the control may be caused by the degradation of sarcoplasmic and myofibrillar proteins.

\subsubsection{Muscle Microstructure}

Scanning electron micrographs of the muscles treated with (20\% BE, w/w) and without BE (control) are shown in Figure 2. The control samples of all the muscle fibers had well organized structure and were closely bound to each other. Whereas in the BE treated samples, there were broken muscle fibers in different bundles, they were less attached, and there was a loss of muscle fibers interaction. Furthermore, there was a disintegration of myofibrillar with a lot of exudates. This produced an increase of interfibrillar space, or voids between muscle fibers, which grew and revealed big gaps between them. These gaps might be due to the degradation of endomysial collagen and sarcolemma surrounding the muscle fibers. The degradation of the muscle structure became evident when looking at the figure. It showed that strong muscle

Beef
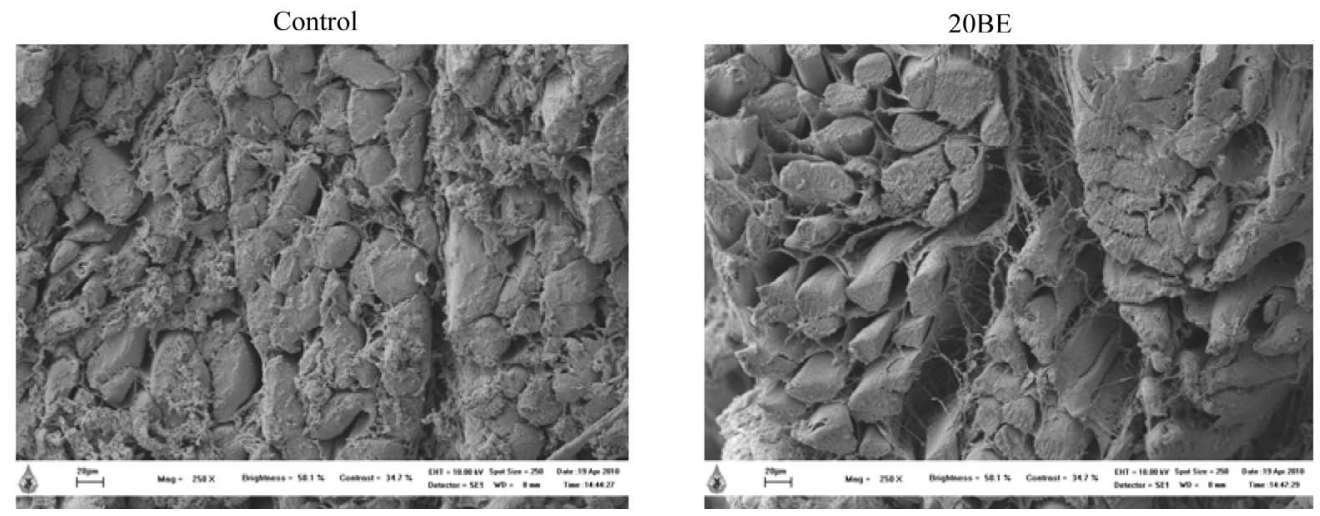

Chicken
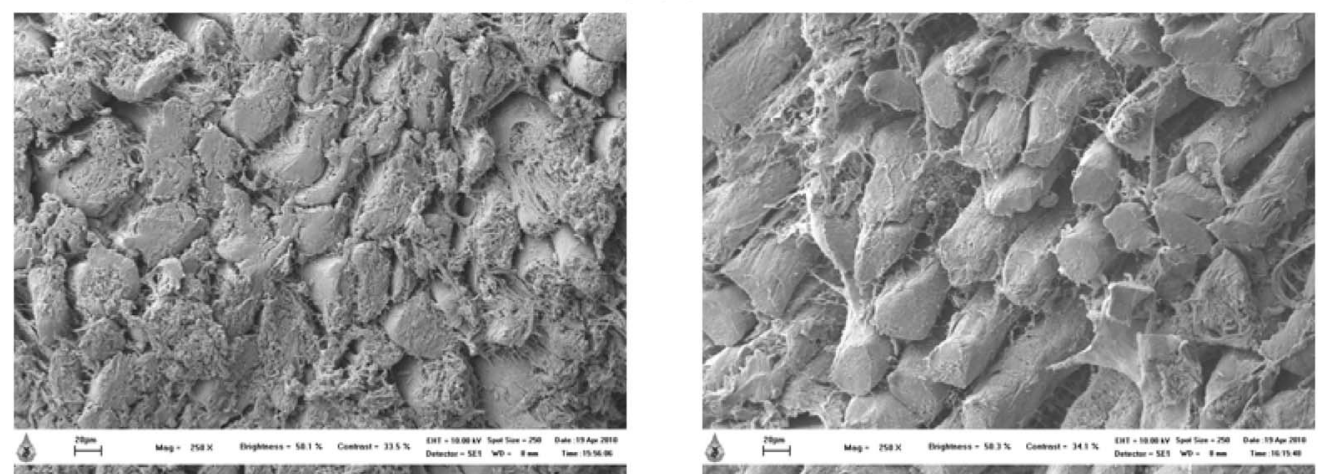

Squid
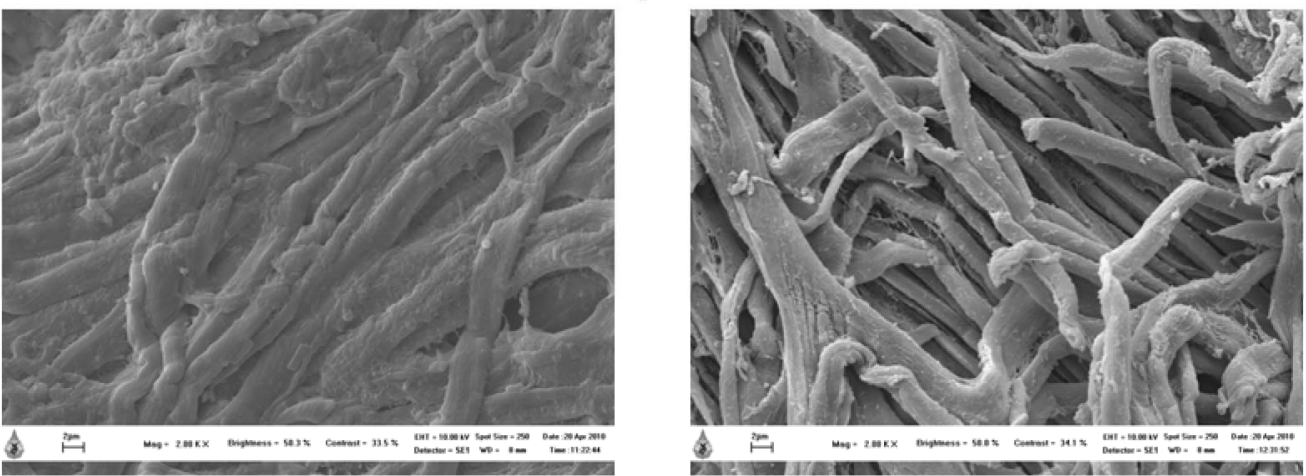

Figure 2. Microstructure of the samples treated without (control) and with $20 \%(\mathrm{w} / \mathrm{w})$ powder of bromelain extract (20 BE). Magnification of $250 \times$ for beef and chicken samples and $2000 \times$ for squid, at acceleration voltage of $10 \mathrm{kV}$. 
fibers were broken and the cell membranes were severely degraded. The junctions of the myofibrillar package and the sarcolemma have disappeared from most cells. Disruption of the intramuscular connective tissue structure is another cause for meat tenderization. The microstructure of the 20 BE samples showed a strong correlation with the previous results in term of textural properties, TCA-soluble peptides content, and SDS-PAGE patterns. Naveena [23] studied the effect of ginger extract on the microstructure of buffalo muscle by using SEM, and they found that the ginger extract treatment broke muscle fibers into different bundles and also increased the space between the bundles. In addition, there was marked deformation and disruption of honey-like structure observed in the beef treated with elastase from the Bacillus strain [2].

\subsection{Effects of Bromelain Extract on the Chemical Properties of Muscle Foods}

\subsection{1. pH and Moisture Content}

A significant decrease in $\mathrm{pH}$ was found in all of the treated samples when compared to the control. The low $\mathrm{pH}$ of $\mathrm{BE}$ (4.07) was probably caused by the lower $\mathrm{pH}$ of the treated samples (Table 1). Moreover, BE hydrolysis of the muscle may result in releasing amino acids that can reduce the $\mathrm{pH}$ of the system. The decrease in $\mathrm{pH}$ of the treated sample (20\% BE, w/w) ranges are 5.28 - 5.24, 5.93 - 5.76 and 7.04 - 6.063, when compared to the control for beef, chicken and squid, respectively. For starting material, the highest $\mathrm{pH}$ was found in the squid muscle. In addition, the most decreased value of $\mathrm{pH}$ was also found in this kind of muscle. The $\mathrm{pH}$ value in meat product is highly important because it has a major influence on other physic-chemical and quality properties such as WHC, tenderness and juiciness [29]. Changes in $\mathrm{pH}$ are caused by postmortem metabolism and also by the application of added substances to the meat during technological processes [30].

The powder of bromelain extract could absorb more water in the fresh meat samples, which resulted in lower moisture content when compared with the control $(p<$ 0.05). The moisture content in the BE-treated samples markedly when decreased compared with the untreated samples (Table 1). Increased BE concentration resulted in moisture content reduction, justified that enzyme treatment improved hydrophilic properties. Besides, it could probably be due to absorption of moisture in the treated meat samples. It is also probably due to the hygroscopic nature of BE powder when attached to the wet surface of the sample. The low moisture content of the treated samples is related to product acceptability for the consumer. It also affects the yield of the final product ( $p$ $<0.05)$. Naveena et al. [25] reported that moisture reten- tion in spent-hen meats treated with ginger rhizome extract as compared with untreated sample. Similar observations were found: $77.18 \%$ moisture in ginger rhizome extract was found in a treated buffalo meat sample as compared with $76.51 \%$ in an untreated one.

\subsubsection{TCA-Soluble Peptides Content}

The highest content of TCA-soluble peptides was found in the chicken, followed by beef and squid muscle treated with 20\% BE (w/w), respectively (Figure 3). When the concentration of BE was increased, the TCA-soluble peptides content in the entire treated sample increased ( $p$ $<0.05)$. The TCA-soluble peptides content was the lowest in the squid muscle. This result coordinates with the protein patterns that show higher intensity for major protein bands (Figure 4, lane 1). More than a 27\% increase of TCA-soluble peptides content was found in the sample treated with $20 \% \mathrm{BE}$ as compared to the control. The highest increase of TCA-soluble peptides content was found in the chicken and the lowest was found in the squid muscle. The tyrosine level indicated that the endogenous oligopeptides and/or free amino acids, as well as degradation products, all accumulated after being marinated with BE. From these results, high TCA-soluble

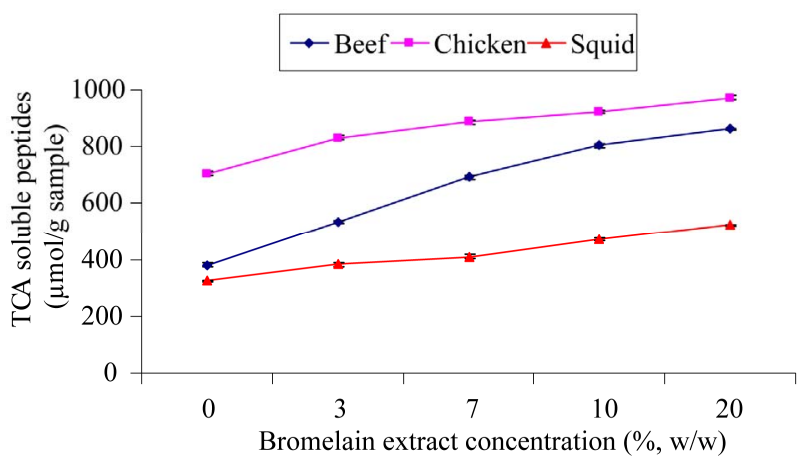

Figure 3. TCA-soluble peptides content of muscle samples treated with different concentrations of bromelain extract.

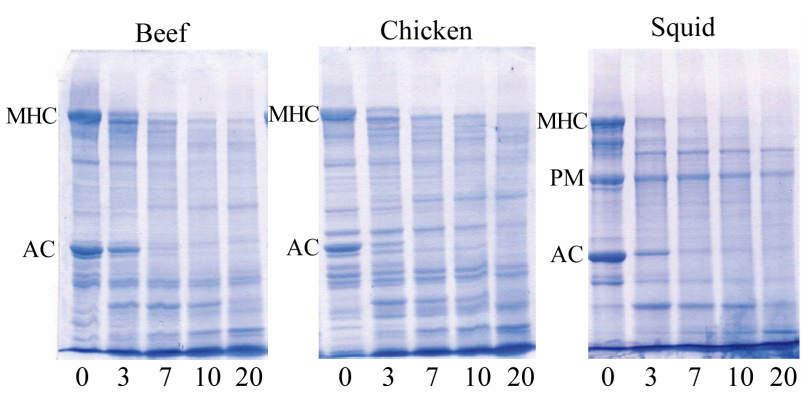

Figure 4. SDS-PAGE patterns of meat samples treated with different concentration of bromelain extract at room temperature for $60 \mathrm{~min}$. Numbers indicated the concentration of bromelain extract addition (\%, w/w), MHC: myosin heavy chains; AC: actin; PM: paramyosin. 
peptides content indicated a greater muscle protein hydrolysis generated by proteolytic enzymes present in BE. The degradation of the myofibrillar proteins resulted in an increase in peptides and free amino acids. Increased TCA-soluble peptides content and free $\alpha$-amino acids were coincidental with the continuous decreased band intensity of the major proteins after being marinated with BE, especially in the chicken muscle (Figure 4, lane 5). Rawdkuen et al. [31] reported that when using protease from Calotropis procera in beef, giant catfish and squid muscles, hydrolytic properties were shown to gradually decrease in numbers of protein bands and band intensity as compared with the control sample.

\subsubsection{Hydrolytic Patterns}

SDS-PAGE patterns are shown in Figure 4. Similar protein patterns in beef and chicken were observed (lane 1), while slightly different compositions in squid muscle were observed. The myosin heavy chain (MHC) and actin (AC) are the major proteins in all muscle foods. Apart from $\mathrm{MHC}$ and $\mathrm{AC}$, a new protein band with high intensity, paramyosin (PM), was observed in the protein patterns of the squid muscle (lane 1). There was increased proteolysis of the muscle proteins in all of the BE treated samples as evidenced by the reduction in the number and intensity of the protein bands when the BE concentration was added. When comparing the treatment (BE-treated) to the control, the MHC band was markedly degraded into lower molecular weight products as shown at the bottom part of the gel. Moreover, degradation of the AC from the $\mathrm{BE}$ addition were also observed on the SDS-PAGE. According to Wada et al. [5], plant thiol proteases affect the structure of MHC and the AC filaments of myofibrillar proteins. Furthermore, these enzymes have very broad specificities, and therefore; indiscriminately break down the major muscle proteins (connective tissue/collagen and myofibrillar proteins), resulting in over-tenderization and a mushy-textured product [32]. From the result, it is also evident that effective cleavage of high MW proteins into low MW proteins was generated.

The degradation of muscle protein plays a major role in determining the tenderness and WHC of meat during the postmortem storage. Myosin constitutes approximately $45 \%$ of the total myofibrillar proteins, and it is the major structural protein in muscle [33]. Myofibrillar proteins such as troponin-T, titin and nebulin are considered to be indicators of the overall extent of postmortem proteolysis and predictors of meat tenderness [34]. The results from the current study appear to confirm this. Also MHC and AC are very stable and do not degrade under normal postmortem conditions [35]. The BE affected the MHC by fragmenting them into small molecular weight protein bands. The BE-treated meat samples were tender, and showed greater induced fragmentation of MHC. Based on these results, it could be determined that $\mathrm{BE}$ potentially has high proteolytic activity, making the meat more tender. Sawdy et al. [36] reported a significant correlation between MHC fragments and meat tenderness in bovine muscle. Similar observations of lower numbers of protein bands in buffalo meat added with ginger and $\mathrm{Cu}$ cumis trigonus extract have been reported. In addition, the increase in proteolysis can be correlated with significantly higher protein solubility. Bhaskar et al. [37] found cleavage of high MW proteins into lower MW proteins when using ginger powder in spent hen meat. Bacterial proteolytic treatment of muscle protein produced a reduction in the level of higher MW fractions due to the degradation of myosin, thus increasing the meat tenderness [38].

\section{Conclusions}

Findings in the present experiment in physic-chemical and quality properties such as significant reductions in shear force values, WHC, cooking loss, TCA-soluble peptides content and electrophoretic pattern of treated muscle proteins showed the effective utilization of bromelain extract from pineapple peels for tenderizing tough muscle foods without adversely affecting other quality parameters. Therefore, technology for applying this enzyme is easily and cheaply available and can be exploited at the household or industrial level for tenderizing tough meat, and it can be used as a better alternative to chemical tenderizers or other plant proteases.

\section{Acknowledgements}

The authors would like to express their sincere thanks to Mae Fah Luang University for partially financing this study. We also thank Prof. Matthew Robert Ferguson, Language Center, Naresuan University for kindly providing suggestions and corrections for the manuscript.

\section{REFERENCES}

[1] C. M. Kemp, P. L. Sensky, R. G. Bardsley, P. J. Buttery and T. Parr, “Tenderness: An Enzymatic View," Meat Science, Vol. 84, No. 2, 2010, pp. 248-256.

doi:10.1016/j.meatsci.2009.06.008

[2] Q. H. Chen, G. Q. He, Y. C. Jiao and H. Ni, "Effects of Elastase from a Bacillus Strain on the Tenderization of Beef Meat," Food Chemistry, Vol. 98, No. 4, 2006, pp. 624-629. doi:10.1016/j.foodchem.2005.06.043

[3] J. A. Melendo, J. A. Beltrin and P. Roncales, “Tenderization of Squid (Loligo vulgaris and Illex coindetii) with Bromelain and Bovine Spleen Lysosomal-Enriched Extract," Food Research International, Vol. 30, No. 5, 1997, pp. 335-341. doi:10.1016/S0963-9969(97)00057-4 
[4] I. N. A. Ashie, T. L. Sorensen and P. M. Nielsen, "Effects of Papain and a Microbial Enzyme on Meat Proteins and Beef Tenderness,” Journal of Food Science, Vol. 67, No. 6, 2002, pp. 2138-2142. doi:10.1111/j.1365-2621.2002.tb09516.X

[5] M. Wada, T. Suzuki, Y. Yaguti and T. Hasegawa, "The Effect of Pressure Treatments with Kiwi Fruit Protease on Adult Cattle Semitendinosus Muscle," Food Chemistry, Vol. 78, No. 2, 2002, pp. 167-171. doi:10.1016/S0308-8146(01)00395-8

[6] B. M. Naveena, S. K. Mendiratta and A. S. R. Anjaneyulu, "Tenderization of Buffalo Meat Using Plant Proteases from Cucumis Trigonus Roxb (Kachri) and Zingiber Officinale Roscoe (Ginger Rhizome)," Meat Science, Vol. 68, No. 3, 2004, pp. 363-369. doi:10.1016/j.meatsci.2004.04.004

[7] V. D. Pawar, B. D. Mule and G. M. Machewad, "Effect of Marination with Ginger Rhizome Extract on Properties of Raw and Cooked Chevon,” Journal of Muscle Foods, Vol. 18, No. 4, 2007, pp. 349-369. doi:10.1111/j.1745-4573.2007.00091.x

[8] Z. Pietrasik, J. L. Aalhus, L. L. Gibson and P. J. Shand, "Influence of Blade Tenderization, Moisture Enhancement and Pancreatin Enzyme Treatment on the Processing Characteristics and Tenderness of Beef Semitendinosus Muscle,” Meat Science, Vol. 84, No. 3, 2010, pp. 512-517. doi:10.1016/j.meatsci.2009.10.006

[9] B. Gerelt, Y. Ikeuchi and A. Suzuki, "Meat Tenderization by Proteolytic Enzymes after Osmotic Dehydration," Meat Science, Vol. 56, No. 3, 2000, pp. 311-318. doi:10.1016/S0309-1740(00)00060-7

[10] K. Palka, "Changes in Intramuscular Connective Tissue and Collagen Solubility of Bovine M. Semitendinosus during Retorting,” Meat Science, Vol. 53, No. 3, 1999, pp. 189-194. doi:10.1016/S0309-1740(99)00047-9

[11] J. R. Claus, J. K. Schilling, N. G. Marriott, S. E. Duncan, M. B. Solomon and H. Wang, "Tenderization of Chicken and Turkey Breasts with Electrically Produced Hydrodynamic Shockwaves,” Meat Science, Vol. 58, No. 3, 2001, pp. 283-286. doi:10.1016/S0309-1740(01)00027-4

[12] A. Sriwatanapongse, M. Balaban and A. Teixeira, "Thermal Inactivation Kinetics of Bromelain in Pineapple Juice," Journal of American Society of Agricultural Engineers, Vol. 43, No. 6, 2000, pp. 1703- 1708.

[13] L. Huang, H. Z. Qu, L. Zhang, S. S. Du, S. Yang, D. Y. Hao and X. P. Wang, "Purification and Characterization of a Proteolytic Enzyme from Fig Latex," Journal of Chemistry, Vol. 24, No. 3, 2008, pp. 348-352.

[14] J. Dreuth, J. Jansonius, R. Koekoek, H. Swen and B. Wolters, "Structure of Papain," Nature, Vol. 218, 1968, pp. 929-932. doi:10.1038/218929a0

[15] E. H. Thompson, I. D. Wolf and C. E. Allen, "Ginger Rhizome: A New Source of Proteolytic Enzyme,” Journal of Food Science, Vol. 38, No. 4, 1973, pp. 652-655. doi:10.1111/j.1365-2621.1973.tb02836.x

[16] S. Ketnawa, S. Sai-Ut, T. Theppakorn, P. Chaiwut and S. Rawdkuen, "Partitioning of Bromelain from Pineapple peel (Nang Lae cultv.) by Aqueous Two Phase System," Asian Journal of Food \& Agro-Industry, Vol. 2, No. 4, 2009, pp. 457-468.

[17] M. Espe, K. Ruohonen, M. Bjornevik, L. Froyland, R. Nortvedt and A. Kiessling, "Interactions between Ice Storage Time, Collagen Composition, Gaping and Textural Properties in Farmed Salmon Muscle Harvested at Different Times of the Year," Aquaculture, Vol. 240, No. 1-4, 2004, pp. 489-504. doi:10.1016/j.aquaculture.2004.04.023

[18] F. B. Wardlaw, L. H. Maccaskill and J. C. Acton, "Effect of Postmortem Muscle Changes in Poultry Meat Loaf Properties,” Journal of Food Science, Vol. 38, No. 3, 1973, pp.421-424. doi:10.1111/j.1365-2621.1973.tb01444.x

[19] AOAC, “Official Methods of Analysis," $16^{\text {th }}$ Edition, Association of Official Analysis Chemists, Washington, 2000.

[20] S. Benjakul, W. Visessanguan, S. Riebroy, S. Ishizaki and M. Tanaka, "Gel-Forming Properties of Surimi Produced from Bigeye Snapper, Priacanthus tayenus and $P$. macracanthus, Stored in Ice," Journal of the Science of Food and Agriculture, Vol. 82, No. 13, 2002, pp. 14421451. doi:10.1002/jsfa.1207

[21] Q. H. Lowry, N. J. Rosebrough, L. A. Farr and R. J. Randall, "Protein Measurement with the Folin Phenol Reagent,” Journal of Biological Chemistry, Vol. 193, No. 1, 1951, pp. 256-275.

[22] U. K. Laemmli, F. Beguin and G. Gujer-Kellenberger, “A Factor Preventing the Major Head Protein of Bacteriophage T4 from Random Aggregation," Journal of Molecular Biology, Vol. 47, No. 1, 1970, pp. 69-74. doi:10.1016/0022-2836(70)90402-X

[23] B. M. Naveena, "The Tenderization of Buffalo Meat Using Ginger Extract,” Journal of Muscle Foods, Vol. 15, No. 4, 2004, pp. 235-244. doi:10.1111/j.1745-4573.2004.06403.x

[24] K. S. Ziauddin, D. N. Rao and B. L. Amla, "Effect of Lactic Acid, Ginger Extract and Sodium Chloride on Electrophoretic Pattern of Buffalo Muscle Proteins," Journal of Food Science and Technology, Vol. 32, No. 3, 1995, pp. 224-226.

[25] B. M. Naveena and S. K. Mendiratta, "Tenderization of Spent Hen Meat Using Ginger Extract,” British Poultry Science, Vol. 42, No. 3, 2001, pp. 344-350. doi:10.1080/00071660120055313

[26] J. C. Forrest, E. D. Aberle, H. B. Hedrick, M. D. Judge and R. A. Merkel, "Principles of Meat Science,” Kendall Hunt Publishing Company, Dubuque, 1994.

[27] S. T. Joo, R. G. Kauffman, B. C. Kim and G. B. Park, "The relationship of Sarcoplasmic and Myofibrillar Protein Solubility to Colour and Water-holding Capacity in Porcine Longissimus Muscle,” Meat Science, Vol. 52, No. 3, 1999, pp. 291-297. doi:10.1016/S0309-1740(99)00005-4

[28] E. Huff-Lonergan and S. M. Lonergan, "Mechanism of Water Holding Capacity of Meat: The Role of Postmor- 
tem Biochemical and Structural Changes,” Meat Science, Vol. 71, No. 1, 2005, pp. 194-204. doi:10.1016/j.meatsci.2005.04.022

[29] T. Goli, P. A. Nakhoul, N. Zakhia-Rozis, G. Trystram and P. Bohuon, "Chemical Equilibrium of Minced Turkey Meat in Organic Acid Solutions," Meat Science, Vol. 75, No. 2, 2007, pp. 308-314. doi:10.1016/j.meatsci.2006.07.016

[30] N. F. S. Gault, “The Relationship between Water-Holding Capacity and Cooked Meat Tenderness in Some Beef Muscles as Influenced by Acidic Conditions below the Ultimate $\mathrm{pH}, ”$ Meat Science, Vol. 15, No. 1, 1985, pp. 15-30. doi:10.1016/0309-1740(85)90071-3

[31] S. Rawdkuen, P. Pintathong, P. Chaiwut and S. Benjakul, "The Partitioning of Protease from Calotropis Procera Latex by Aqueous Two-Phase Systems and Its Hydrolytic Pattern on Muscle Proteins," Food and Bioproducts Processing, Vol. 50, No. 3, 2010, pp. 145-149.

[32] A. J. Miller, E. D. Strange and R. C. Whiting, "Improved Tenderness of Restructured Beef Steaks by a Microbial Collagenase Derived from Vibrio B-30," Journal of Food Science, Vol. 54, No. 4, 1989, pp. 855-857. doi:10.1111/j.1365-2621.1989.tb07898.x

[33] S. Schiaffino and C. Reggiani, "Molecular Diversity of Myofibrillar Proteins: Gene Regulation and Functional Significance,” Physiology Reviews, Vol. 76, No. 2, 1996, pp. 371-423.

[34] E. Huff-Lonergan, F. C. Parrish and R. M. Robson, "Effects of Postmortem aging Time, Animal Age and Sex on Degradation of Titin and Nebulin in Bovine Longissimus Muscle,” Journal of Animal Science, Vol. 73, No. 4, 1995, pp. 1064-1073.

[35] E. Bandman and D. Zdanis, "An Immunological Method to Assess Protein Degradation in Postmortem Muscle," Meat Science, Vol. 22, No. 1, 1988, pp. 1-19. doi:10.1016/0309-1740(88)90023-X

[36] J. C. Sawdy, S. A. Kaiser, N. R. St-Pierre and M. P. Wick, "Myofibrillar 1-D Fingerprints and Myosin Heavy Chain MS Analyses of Beef Loin at $36 \mathrm{~h}$ Postmortem Correlate with Tenderness at 7 Days," Meat Science, Vol. 67, No. 3, 2004, pp. 421-426. doi:10.1016/j.meatsci.2003.11.014

[37] N. Bhaskar, N. M. Sachindra,V. K. Modi, P. Z. Sakhare and N. S. Mahendrakar, "Preparation of Proteolytic Activity Rich Ginger and Evaluation of Its Tenderizing Effect of Spent-Hen Muscles," Journal of Muscle Foods, Vol. 17, No. 2, 2006, pp. 174-184. doi:10.1111/j.1745-4573.2006.00043.x

[38] V. K. Jorgova, S. Danchev and A. Kostov, "Effect of Bacterial Enzyme Preparation on the Solubility and Electrophoretic Properties of Muscle Proteins,” Proceedings International Congress of Meat Science and Technology, Vol. 35, 1989, pp. 913-917. 